\title{
In memoriam Carl W. Rettenmeyer (1931-2009)
}

\section{S. O'Donnell}

Published online: 19 June 2011

(C) International Union for the Study of Social Insects (IUSSI) 2011

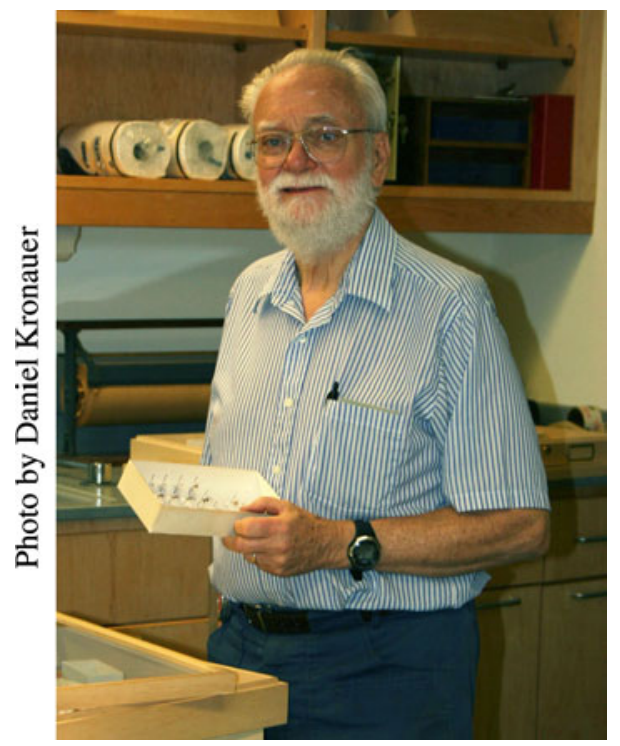

This essay honors the memory of esteemed colleague Carl W. Rettenmeyer, who passed away on 9 April 2009. The essay accompanies a set of contributed scientific papers on army ant biology in this issue (pp 279-343). These papers celebrate Carl's legacy and his ongoing influence on tropical social insect biology research. An obituary for Carl was recently published by fellow army ant biologist William Gotwald (2009). Here I write in memory of Carl as an inspirational scientist as well as a wonderful and generous man. To this end I asked contributors to the Insectes Sociaux Rettenmeyer memorial paper collection to share their

S. O’Donnell ( $\square)$

Department of Psychology, University of Washington,

Box 351525, Seattle, WA 98195, USA

e-mail: sodonnel@uw.edu thoughts and memories of Carl as a professional colleague and as a person. Two themes emerged: Carl was both a truly inspirational researcher, and a warm and generous man who shared his enthusiasm and knowledge freely.

I will open by noting that Carl's research was highly influential to my career development. I clearly remember the thrill in graduate school of being transported to the tropics (during hard Wisconsin winters) by Carl's scientific papers, and those of his students (Chadab, 1979). Carl's writings on general army ant biology (Rettenmeyer, 1963), chemical communication (Chadab and Rettenmeyer, 1975), and foraging behavior (Rettenmeyer et al., 1983) could inspire like few others. Like army ants themselves, Carl's influence reaches far. Carl may have been the first professional biologist to visit Monteverde, Costa Rica, which developed into a major center for Neotropical research and conservation (Campbell, 2001). Carl's work generated research on topics as diverse as avian ecology (Wrege et al., 2005), social insect symbioses (Eickwort, 1990), tropical phenology (Kaspari et al., 2001), chemical communication (Billen and Gobin, 1996) and conservation biology (Boswell et al., 1998). His combination of a good eye for important questions and evident rigor in field data collection are exemplary in the annals of tropical biology.

Carl was supportive as a mentor to young biologists who shared his interests, both for people who worked closely with him and those who corresponded with him. Daniel Kronauer contacted Carl in 2003 at the beginning of a new army ant research project: "Because Carl had retired a while ago, I assumed that at this point he would probably not be particularly interested to hear about my work. It turned out that I could not have been more mistaken. Carl was thrilled to find out that I was working on army ants, and what ensued was a vivid exchange of emails over the years to come." 
Johel Chaves similarly noted Carl's generous advice and encouragement in designing his work on ant/bird interactions. As Stefanie Berghoff recounted, "simply sending a reprint when one showed interest in army ant associates was not at all like Carl. He invited me first to his house and then to go on a field trip to Costa Rica for a small project on army ant associates. So it was Carl, who first introduced me to Neotropical army ants and their associates."

It was not until the 2006 IUSSI International Congress in Washington, DC that I had the great pleasure and honor of meeting the man who had so shaped my work. One evening Carl and Bill Gotwald assembled a surprisingly large crew of army ant enthusiasts for a dinner out. I was lucky enough to sit with Carl and his wife Marion at the end of the long table, sharing army ant stories and dreaming of tropical adventures yet to come. Carl also showcased his new DVD on army ant biology at these meetings, and the film has become a staple at my house. As the memorial papers show, Carl's work and support have inspired and nurtured the next generation of army ant researchers.

\section{References}

Billen J. and Gobin B. 1996. Trail following in army ants (Hymenoptera, Formicidae). Neth. J. Zool. 46: 272-280
Boswell G.P., Britton N.F. and Franks N.R. 1998. Habitat fragmentation, percolation theory and the conservation of a keystone species. Proc. R. Soc. Lond. B 26: 1921-1925

Campbell J. 2001. Biologists. In: Monteverde Jubilee Family Album (Guindon L., Moss M., Rockwell M., Trostle J. and Trostle S., Eds). Monteverde Friends Meeting. pp 170-171

Chadab R. 1979. Early warning cues for social wasps attacked by army ants. Psyche 86: 115-122

Chadab R. and Rettenmeyer C.W. 1975. Mass recruitment by army ants. Science 188: 1124-1125

Eickwort G.C. 1990. Associations of mites with social insects. Annu. Rev. Entomol. 35: 469-488

Gotwald W.H. 2009. In memoriam - Carl W. Rettenmeyer (19312009). Myrmecol. News 12: 250

Kaspari M., Pickering J., Longino J.T. and Windsor D. 2001. The phenology of a Neotropical ant assemblage: evidence for continuous and overlapping reproduction. Behav. Ecol. Sociobiol. 50: $382-390$

Rettenmeyer C.W. 1963. Behavioral studies of army ants. Univ. Kansas Scient.Bull. 44: 281-465

Rettenmeyer C.W., Chadab-Crepet R., Naumann M.G. and Morales L. 1983. Comparative foraging by Neotropical army ants. In: Social Insects in the Tropics (P. Jaisson, Ed), Université Paris-Nord. pp 59-73

Wrege P.H., Wikelski M., Mandel J.T., Rassweiler T. and Couzin I.D. 2005. Antbirds parasitize foraging army ants. Ecology 86: 555-559 